\title{
Experimental dry socket. Microscopic and molecular evaluation of two treatment modalities $^{1}$
}

\author{
Alveolite experimental. Análise microscópica e molecular de duas modalidades de tratamento
}

\author{
Camila Lopes CardosoI, Osny Ferreira Júnior", Paulo S. Perri de Carvalho ${ }^{\mathrm{III}}$, Thiago José Dionísio ${ }^{\mathrm{IV}}$, Tânia Mary Cestariv, \\ Gustavo Pompermaier Garlet ${ }^{\mathrm{VII}}$
}

\begin{abstract}
${ }^{1}$ Research performed at Department of Oral Surgery, Bauru School of Dentistry, University of Sao Paulo (USP), Brazil.
${ }^{\mathrm{I}} \mathrm{PhD}$, Department of Oral Surgery, Bauru School of Dentistry, USP, Bauru-SP, Brazil. Main author. Responsible for conception, design, intellectual and scientific content of the study and surgical procedures.

${ }^{\text {II }} \mathrm{PhD}$, Associate Professor, Department of Oral Surgery, Bauru School of Dentistry, USP, Bauru-SP, Brazil. Tutor. Responsible for conception and critical revision of the study.

${ }^{\mathrm{III}} \mathrm{PhD}$, Full Professor, Department of Oral Surgery, Bauru School of Dentistry, USP, Bauru-SP, Brazil. Tutor. Responsible for conception and critical revision of the study.

${ }^{\text {IV }}$ PhD, Technical Assistant, Department of Biological Sciences, Bauru School of Dentistry, USP, Bauru-SP, Brazil. Laboratory procedures.

${ }^{\vee}$ PhD, Technical Assistant, Department of Biological Sciences, Bauru School of Dentistry, USP, Bauru-SP, Brazil. Surgical procedures and microscopic analysis.

${ }^{\mathrm{VI}} \mathrm{PhD}$, Associate Professor, Department of Biological Sciences, Bauru School of Dentistry, USP, Bauru-SP, Brazil. Tutor. Responsible for molecular analysis.
\end{abstract}

\begin{abstract}
PURPOSE: To evaluate two treatment modalities of dry socket in rats and to discuss the first findings of the molecular analysis in this experimental model.

METHODS: 84 rats underwent a tooth extraction were divided in 4 groups: I-uninfected socket (control), II-infected socket without any treatment, III-infected socket treated with irrigation of $2 \%$ sodium iodide and $3 \%$ hydrogen peroxide solution, IV-infected socket submitted to curettage, irrigation with physiological saline solution and fulfilled with metronidazole paste as base. The groups were subdivided in postoperative sacrifice periods: 6/15/28 days. A quantitative and a qualitative microscopic analysis was performed. Also, a quantitative analysis was performed using a RealTimePCR to evaluate the genes expression in the wound healing: Collagen Type I/COL-I, vascular endothelial growth factor/VEGF, osteocalcin/OCN, alkaline phosphatase/ALP, runt-related transcription factor 2/ RUNX2 and tumor necrosis factor alpha/TNF- $\alpha$.

RESULTS: The group I showed higher bone formation, followed by groups IV, III, II respectively. The group II presented higher inflammatory infiltrate and the wound healing was delayed compared with other groups. It was obtained a significant positive correlation between bone neoformation and the expression of OCN and RUNX2, inflammatory infiltrate with TNF- $\alpha$ and a negative correlation between bone neoformation and TNF- $\alpha$.
\end{abstract}

CONCLUSION: No significant difference was found between the treatments.

Key words: Wound Healing. Dry Socket. Hydrogen Peroxide. Sodium Iodide. Metronidazole. Rats.

\section{RESUMO}

OBJETIVO: Avaliar duas modalidades de tratamento da alveolite em ratos e discutir os primeiros achados de uma análise molecular neste modelo experimental.

MÉTODOS: 84 ratos foram submetidos a uma extração dentária e foram divididos em quatro grupos: I- alvéolo não infectado (controle), II- alvéolo infectado sem tratamento, III- alvéolo infectado tratado com irrigação de iodeto de sódio a $2 \%$ e solução de peróxido de hidrogênio a 3\%, IV- alvéolo infectado submetido à curetagem, irrigação com solução salina fisiológica e preenchimento com pasta a base de metronidazol. Os grupos foram subdivididos em períodos de sacrifício pós-operatório: 6/15/28 dias. Uma análise quantitativa e qualitativa microscópica foi realizada. Além disso, uma análise quantitativa foi realizada utilizando RealTimePCR para avaliar a expressão de genes no reparo alveolar: o colágeno tipo I / COL-I, o fator de crescimento endotelial vascular / VEGF, osteocalcina / OCN, fosfatase alcalina / ALP, fator de transcrição runt relacionados 2 / RUNX2 e fator de necrose tumoral alfa / TNF- $\alpha$.

RESULTADOS: O grupo I mostrou maior formação óssea, seguido pelos grupos IV, III, II, respectivamente. O grupo II apresentou maior infiltrado inflamatório e a cicatrização foi atrasada em comparação com outros grupos. Foi obtida uma correlação positiva entre a neoformação óssea e a expressão de OCN e RUNX2, infiltrado inflamatório com TNF- $\alpha$ e uma correlação negativa entre a neoformação óssea e TNF- $\alpha$.

CONCLUSÃO: Nenhuma diferença significativa foi encontrada entre os tratamentos.

Descritores: Cicatrização. Alvéolo Seco. Peróxido de Hidrogênio. Iodeto de Sódio. Metronidazol. Ratos 


\section{Introduction}

Dry socket is the most common postoperative complication following a tooth extraction, that onsets 2 to 4 days after surgery ${ }^{1-4}$. It was described for the first time by Crawford ${ }^{5}$. The exact etiology of dry socket is not defined yet, but it is known that several local and systemic factors contribute for which are described in the literature. Several attempts to manage dry socket have been described ${ }^{6,7}$ in the literature employing a variety of materials, irrigation solutions and procedures within the socket, however, the best treatment modality has not been set. Indeed, each institution adopts a different protocol, and in spite of many studies and publications ${ }^{4}$, further investigations are still required to establish the best way to treat this problem.

Dry socket slows the process of wound healing and since the exact mechanisms involved in its onset are not completely known, to become difficult to prevent and to develop the most effective therapeutic strategy. Experimental rat models may be extremely useful to dry socket studies, since they present several advantages including easy handling, availability of experimental reagents and susceptibility of dry socket induction ${ }^{6-8}$.

The purpose of this study was to evaluate the response of two treatments modalities and the biological mechanisms involved in the repair of socket intentionally infected in rats throughout the microscopic and molecular analysis.

\section{Methods}

\section{Experimental dry socket}

Eighty four, 10 week-old male rats (Rattus novergicus albinus, Wistar) weighing about $250 \mathrm{~g}$ were used in this study. The animals were submitted previously to coproparasitological test in which pathogenic parasites were not found. They were kept in individual cages disinfected and covered by sterile sawdust. The experimental protocol was approved by the local Institutional Committee for Animal Care and Use and followed the Council for International Organization of Medical Sciences (CIOMS) ethical code for animal experimentation.

For surgical interventions, the animals received anesthesia with a combination of ketamine and xylazine chloride via intramuscular injection. After asepsis, the maxillary right central incisor was extracted. (Figure 1 A-B) The animals were randomly assigned to 4 groups: I-uninfected socket, II-infected socket without any treatment, III-infected socket treated with irrigation of $2 \%$ sodium iodide and $3 \%$ hydrogen peroxide solution at 1:1 proportion, IV-infected socket submitted to curettage, irrigation with physiological saline solution and fulfilled with metronidazole paste as base. After the extraction, the experimental groups received an intra-alveolar application of epinephrine solution 1:1000 with an absorbent paper point during 1 minute (Figure $1 \mathrm{C}$-D) followed by application of a provided suppurative secretion obtained from donor rats. (Figure 1E) The presence of 39 subgingival species was investigated in the inoculation material by checkerboard DNA-DNA hybridization ${ }^{9}$. This procedure resulted in dry socket clinically detectable after 3 days from extraction (Figure 1F). Only the group III and IV were treated, with irrigation of $2 \%$ sodium iodide and $3 \%$ hydrogen peroxide solution and curettage, irrigation with physiological saline solution and fulfilled with metronidazole paste as base, respectively (Figure 2). At 6, 15 , and 28 post-extraction days, 28 animals from each group were euthanized with a massive dose of anesthetics; 16 for microscopic analysis and 12 for molecular, divided by period.

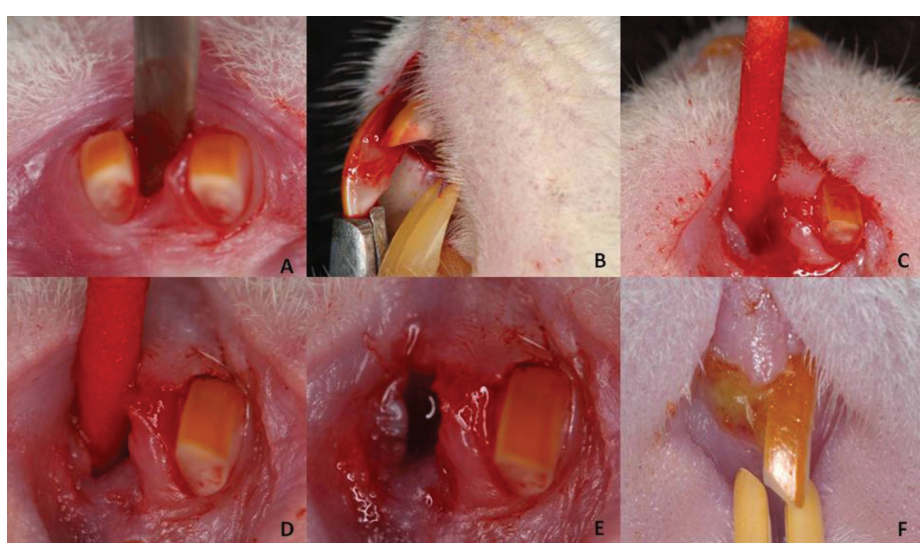

FIGURE 1 - Experimental dry socket induction in rats: A) Luxation of right maxillary incisor; B) Extraction; C) Application of adrenaline solution 1:1000 1 minute; D) Inoculation of purulent secretion into the socket; E) Socket aspect after ischemia and contamination; F) Socket aspect after 3 days of contamination showing pus and gingival edema.

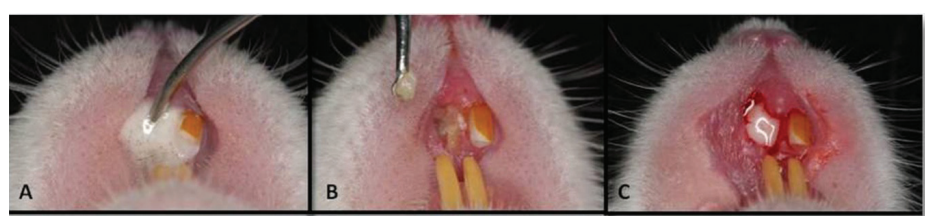

FIGURE 2 - Treatment of the experimental groups: A) Group III: Irrigation with sodium iodide $2 \%$ and hydrogen peroxide $3 \%(1: 1)$; B) Group IV: Curettage and C) Fulfillment with metronidazole pasta as base.

\section{Histometric analysis}

Samples were fixed in $10 \%$ buffered formalin for 7 days, decalcified in $4.7 \%$ EDTA $\mathrm{pH} 7.0$ for 35 days, histologically 
processed, and embedded in paraffin wax. All samples were embedded to provide longitudinal cuts. Semi-serial longitudinal sections of $5 \mu \mathrm{m}$ each were obtained and stained by hematoxylineosin for evaluation by light microscopy. For histometric analysis was selected 45 histological fields per socket by systematic randomization. The histological quantified variables were: bone, connective tissue, inflammatory infiltrate, blood clot and blood vessels. Based on 100 points of the grid, the variables counts were expressed by density and the results were expressed by mean of density observed in each group and analyzed period.

\section{Molecular analysis}

\section{$\underline{\text { Real-time polymerase chain reaction amplification }}$}

The extraction of total RNA from socket were performed with Trizol reagent (Invitrogen) and the cDNA synthesis were accomplished as previously described ${ }^{10}$. RealTime-PCR quantitative mRNA analyses were performed in a MiniOpticon system (BioRad), using SybrGreenMasterMix (Invitrogen), $100 \mathrm{nM}$ specific primers, and $2.5 \mathrm{ng}$ of cDNA in each reaction. Primer pairs for each of the amplification reactions were designed from mRNA sequences of target genes, using the program Primer Express (Applied Biosystems), which the properties of each reaction are described in Table 1. Negative controls without cDNA and without the primer/probe sets were also performed. Calculations for determining the relative levels of gene expression were made from duplicate measurements of the target gene, with normalization to $\beta$-actin in the sample, using the cycle threshold $(\mathrm{Ct})$ method and the $2^{\Delta \Delta \mathrm{ct}}$ equation, as previously described ${ }^{10}$.

TABLE 1 - Properties of each reaction and sequences of primers for Beta-Actina, Collagen Type I/COL-I, vascular endothelial growth factor/VEGF, osteocalcin/OCN, alkaline phosphatase/ALP, runt-related transcription factor 2/RUNX2 and tumor necrosis factor alpha/TNF- $\alpha$, designed by Primer Express program.

\begin{tabular}{c|c|c|c|c}
\hline $\begin{array}{c}\text { T Target Primers } \\
\text { (SPECIFIC FRAGMENTs } \\
\text { OF NUCLEIC ACIDS) }\end{array}$ & $\begin{array}{c}\text { Base } \\
\text { Pairing }\end{array}$ & $\begin{array}{c}\text { Annealing } \\
\text { Temperature }\end{array}$ & $\begin{array}{c}\text { Sense (5'-3') } \\
\text { Forward sequence }\end{array}$ & $\begin{array}{c}\text { Anti-sense (5' } \mathbf{3}^{\prime} \text { ) } \\
\text { Reverse sequence }\end{array}$ \\
\hline$\beta-$ Actina & 150 & 60 & ATTGAACACGGCATTGTCACC & GGTCATCTTTTCACGGTTGGC \\
\hline OCN & 57 & 61 & TACAAGCGCATCTATGGCACC & TGTGCCGTCCATACTTTCGAG \\
\hline ALP & 57 & 61 & CGAGCAGGAACAGAAGTTTGC & TGGCCAAAAGGCAGTGAATAG \\
\hline RUNX2 & 53 & 60 & TTCAAGGTTGACCCTCGGA & AGATCGTTGAACCTGGCCACT \\
\hline VEGF & 172 & 61 & GCCCATGAAGTGGTGAAGTT & ACTCCAGGGCTTCATCATTG \\
\hline TNF- $\alpha$ & 128 & 62 & GAGGCTCTCCCCAAAAAGATG & CCAATCACCCCGAAGTTCAGT \\
\hline
\end{tabular}

Data normality was verified by Kolmogorov-Smirnov test. Data description was done by mean and 95\% confidence interval of mean. Student's t test or Mann-Whitney Rank Sum Test (T) was applied when the groups were compared in each period. One-way ANOVA or Kruskal-Wallis followed by Tukey's or Dunn's test took place when periods 6, 15 and 28 days were compared in each group. The analysis of possible correlations between microscopically and molecularly variables examined were investigated by linear regression test.

\section{Results}

Group I showed higher bone formation, followed by groups IV, III, II respectively (Figure 3A). Group II presented higher inflammatory infiltrate and the wound healing was delayed compared to other groups. Groups III and IV presented higher amount of inflammatory infiltrate than Group I. However, along time, there was a decrease in all groups, and at 28 days, except group II (Figure 3B). The amount of blood vessels increased along time for all the groups and the difference was not significant (Figure $3 C)$. Concerning clot density, group I presented minimum amount at 28 days, and group II higher density at 6 and 15 days. There was not difference between groups III and IV (Figure 3D). Although the conjunctive tissue did not present significant difference of density between the groups, a qualitative difference was observed, and at 28 days, only group II presented floppy conjunctive tissue (Figure 3E). 


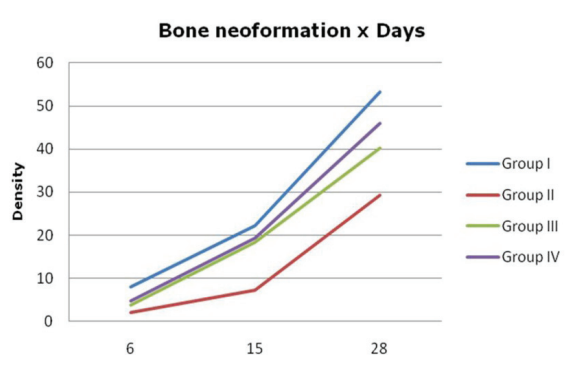

Figure 3A

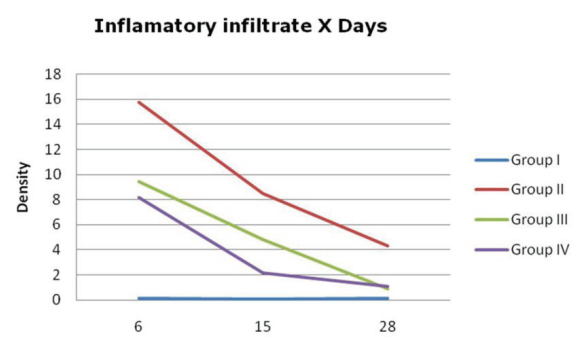

Figure 3B

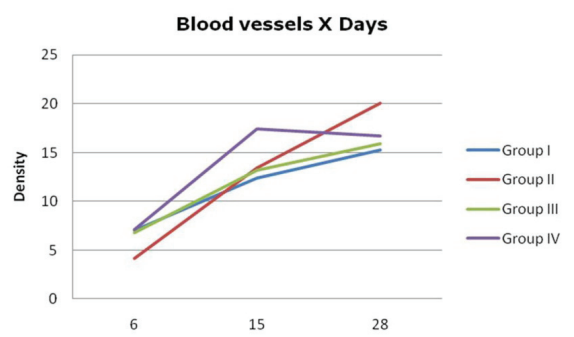

Figure 3C

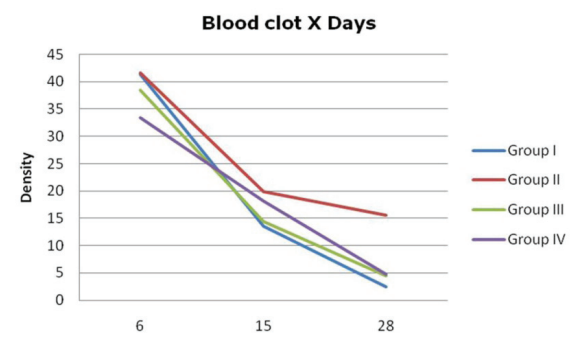

Figure 3D

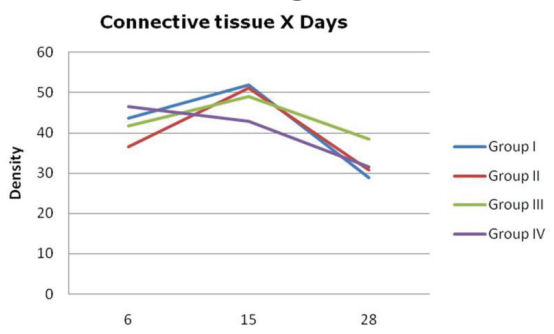

Figure 3E
In relation to bone neoformation markers, RUNX2 had its expression augmented along time for all the groups, including group II, although the last one presented least expression. Group I presented higher expression, and groups III and IV presented few differences (Figure 4A). Groups I and IV presented higher levels of OCN at 15 days. After 15 days, there was a fall for both groups, and at 28 days, a lower expression of OCN. Groups II and III presented a distinct kinetic, in which a gradual increase on the expression of OCN was observed along time, without decrease, observed in the other groups (Figure 4B). The minimum expression of ALP and COL-I was observed in group II (Figure 4 C-D). In relation to TNF- $\alpha$, group II presented higher expression during all the periods, while the lowest expression was for group I (Figure 4E). In relation to the VEGF expression, group II was the only one which presented a different outcome, increasing as time passed by. The other groups presented a decrease on the period concerning 6 to 15 days and an increase of expression at 28 days, as observed in Figure 4F.

FIGURE 3 - Microscopic analysis. A) Bone neoformation density; B) Inflammatory infiltrate density; C) Blood vessels density; D) Blood clot density; E) Connective tissue density. 


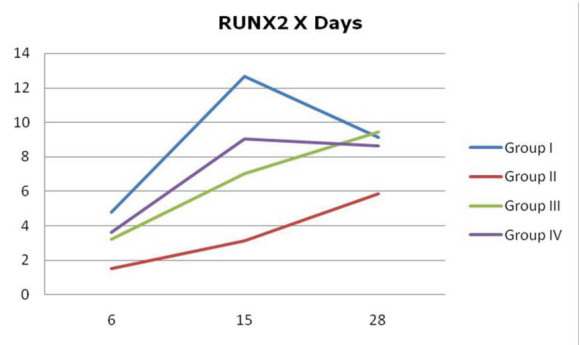

Figure 4A

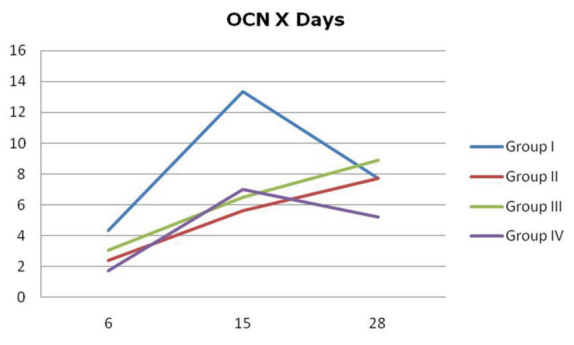

Figure 4B

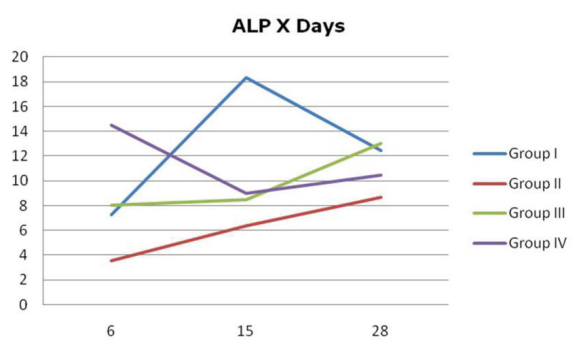

Figure 4C

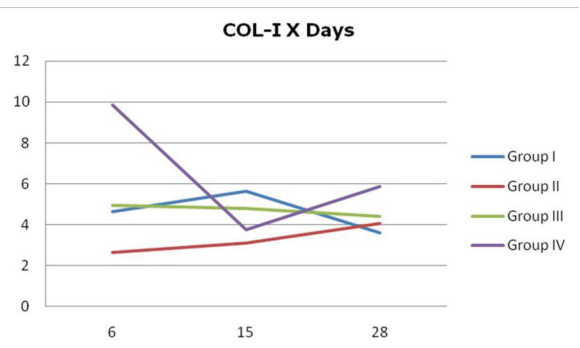

Figure 4D

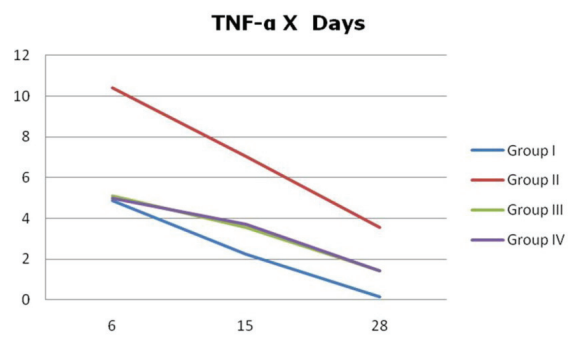

Figure 4E

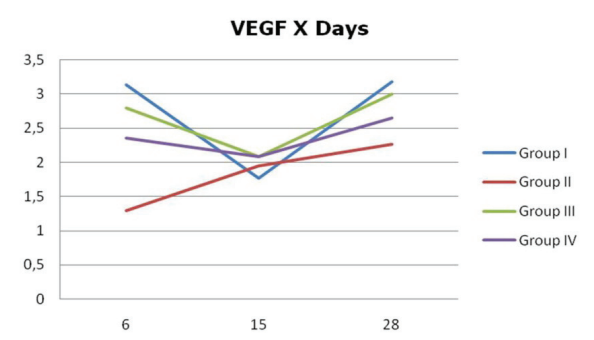

Figure 4F

FIGURE 4 - Molecular analysis. Expression of A) RUNX2; B) OCN; C) ALP; D) COL-I; E) TNF- $\alpha$; F) VEGF, respectively, in each group in all periods.

A significant positive correlation was obtained between bone neoformation and the expression of OCN and RUNX2 as well as between inflammatory infiltrate and TNF- $\alpha$ and negative correlation between bone neoformation and the expression of TNF- $\alpha$ (Figure 5).
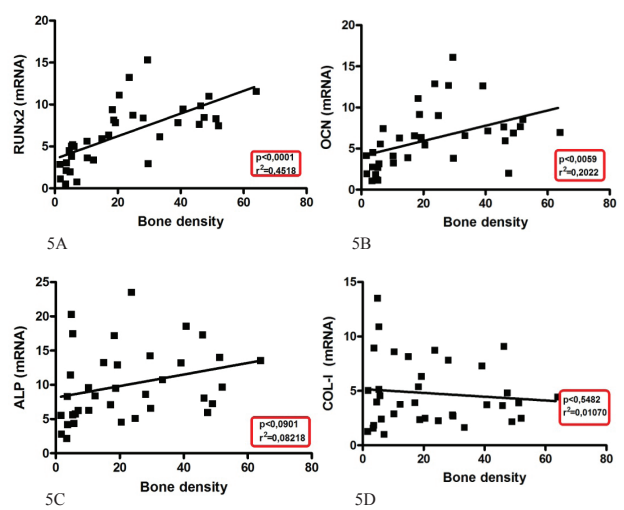

$5 \mathrm{~B}$
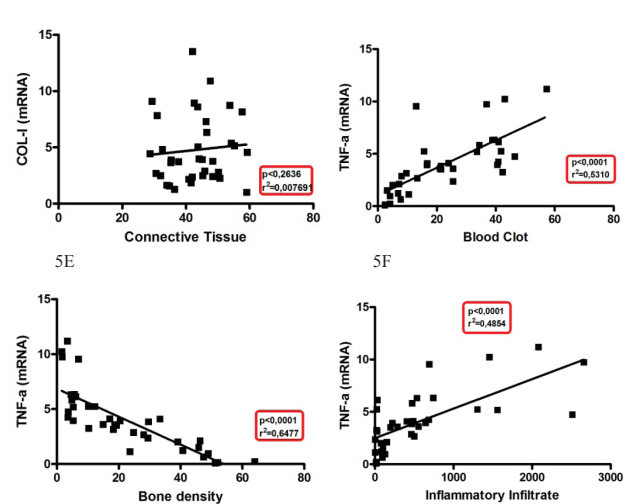

$5 \mathrm{G}$
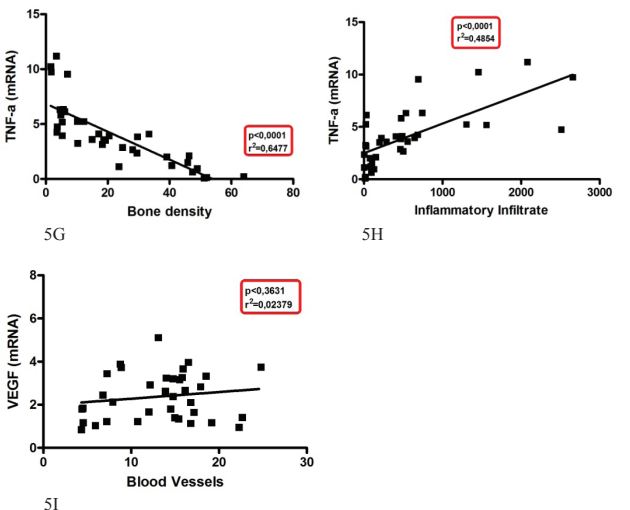

FIGURE 5 - Correlations between microscopically and molecularly variables examined were investigated by linear regression test. 


\section{Discussion}

Based on the literature, it is not possible to find an ideal or consensual treatment protocol ${ }^{4}$. Indeed, each institution adopts a different protocol, and despite many studies and publications, further investigations are still required to establish the best way to treat this problem.

Due to the experiments which demonstrated the role of anaerobic bacteria in the oral infections, among them dry socket, some topic antiseptic combinations capable of releasing great amount of oxygen, seem to be effective to fight against those organisms. An example of those combinations is sodium iodide and hydrogen peroxide. Hydrogen peroxide is an unstable composite, which is easily dissociated in molecular oxygen and water. The solution therapeutically employed is peroxide solution at $3 \%$. When it gets in contact with the tissue, oxygen is released and the germicide action takes place. This effervescence mechanism induces wounds cleaning and debris removal. The combination of iodine-based substances with hydrogen peroxide may bring some advantages ${ }^{4}$. Our institution adopts the following protocol: irrigation of the socket applying hydrogen peroxide at $3 \%$ and sodium iodide at $2 \%$, proportion $1: 1$ and a superficial curettage of the remains and this procedure has presented satisfactory clinical results. Other institutions make curettage, irrigation with physiological saline solution and filling with metronidazole based paste, resulting in clinical success. In the view of our clinical experience, we believe that an aggressive curettage may cause a greater trauma to the osseous alveolar tissues and bacteremia. There are not any studies comparing these two treatment modalities, for this reason we realized this research.

Regarding the use of rat socket, the method presented in this study was based on previous works, which originated a large number of studies ${ }^{8,11,12}$. In this experimental model, even considering the differences concerning to the animal resistance and chronology of alveolar healing, it may simulate situations that could occur in humans.

The microscopic analysis for the study of dry socket is unanimous in the literature $\mathrm{r}^{6,7,8,11,12}$ however the molecular analysis has not been described. With the advent of molecular biology, it becomes possible to study the wound healing process and induced dry socket in rats, employing the technique RealtimePCR, in order to investigate the behavior of some genes in normal wound healing and infection. The molecular analysis is a practical and fast way, therefore there is an interest to validate this analysis in the study of alveolar repair, because the microscopic analysis takes a long time of histotechnical processing and morphometric analysis.
In microscopy analysis, we visualize what is happening and it is possible to quantify and qualify the structures. The molecular analysis allows the expression of the gene which controls the production of these structures, so there should be a correlation between the expression of those genes and the presence of the structures visualized microscopically. Accordingly, we selected some factors involved in bone metabolism and wound healing, such as OCN, ALP, RUNX2, COL-I, VEGF, TNF- $\alpha$. In view of this pioneering work, it was not possible to compare with other studies about wound healing.

According to the information about alveolar process repair in normal conditions, we can observe that, microscopically, group I (control) presented what was expected during all the periods examined, showing a gradual increase, topping higher density of bone neoformation at 28 days, different from group 2, which presented infected socket without any type of treatment, showed lower bone neoformation than the other groups during all the periods analyzed. Groups III and IV were very similar during the periods of time and both presented lower bone neoformation comparing to control group. Other authors obtained similar results when studied the repair process in infected socket of rats after treatment using the same paste (metronidazole) of us, although in our study, all the groups presented higher density of bone neoformation in all the periods ${ }^{13}$.

Comparing the bone neoformation density with biochemical markers of the bone metabolism, a significant positive correlation was obtained among the bone neoformation and the markers OCN and RUNX2 (Figure $5 \mathrm{~A}-\mathrm{B}$ ). Nonetheless, the OCN expresses bone neoformation and the groups I and IV presented higher levels of the OCN and higher osseous tissue density. In relation to kinetic of OCN expression, at 28 days, the socket were totally repaired, presenting decrease on the osteoblasts activity and consequently, a lower production of OCN was expected. Group IV presented a kinetic of expression similar to group I, with lower levels of OCN expression, and it could be justified, jointly with the socket infection, lower bone density presented by group IV when compared to group I. In relation to groups II and III, considering the delay of the repair process, due to untreated infection or treated with hydrogen peroxide, which presents toxic action upon some cells, it is possible that the maintenance of the OCN expression may reflect the maintenance of the osteoblastic activity for a longer period, in order to complete the repair process.

ALP is another bone neoformation marker and it is related to osseous mineralization. Different from described to OCN, there was not significant correlation between the variables of osseous tissue and the ALP levels (Figure 5C), but in group 
II, its expression was lower and bone neoformation also lower too. (Figure 3A,4C). The marker RUNX2 is responsible for the stimulus of differentiation of the precursor cells in osteoblasts and it had its expression increased during time in all the groups, being higher in group I, lower in group II and showed a small difference between groups III and IV (Figure 4A). The expression of RUNX2 between groups, during time, was very similar to the bone neoformation density. The groups which expressed more RUNX2 presented higher bone neoformation (Figure 3A,4A). The correlations between bone neoformation and the OCN, RUNX2 and ALP markers, may probably be due to a higher stimulus for releasing these factors in the initial phase, when the tissue is still immature. Along time and with the presence of RUNX2, there is a higher proliferation of osteoblasts, which result in bone neoformation. The expression of these variables for control group is in agreement to the expected results for normal repair process (Figure 5 A-C).

For group II, it is possible to observe qualitatively and quantitatively a significant delay, due to the contamination and absence of treatment. The minimally bone neoformation present may be probably due to the low expression of the markers observed. RUNX2 presenting lower expression resulted in the osteoblasts differentiation and consequently, there was a lower production of other factors caused by them, resulting in a lower bone neoformation density.

In relation to conjunctive tissue density, qualitatively, there was significant difference between the groups along the periods. At 28 days, group II still presented a lot of floppy conjunctive tissue, probably due to the delay on the repair caused by the contamination and absence of treatment coinciding to a lower amount of osseous tissue. The expression of COL-I and the conjunctive tissue density did not present significant positive correlation. On the initial phase of the repair process, there is a predominant collagen formation, mainly type I (COL-I), one of the main components of the tissues. The least expression of collagen in all the periods was in group II, which presented higher floppy conjunctive tissue density during all the periods (Figure 4D). Thus, the absence of correlation between the expression of collagen and the morphometric variables: conjunctive tissue and bone neoformation probably is due to the presence of collagen in both tissues, which presented a distinct expression along the repair process. This suggests that the analysis of the mRNA for type I collagen is not a reliable marker for analysis of the alveolar repair.

The intention of quantifying the TNF- $\alpha$ was due to the fact that the presence of this cytokine is high on the inflammation, acting importantly on the migration process, even upon the endothelium as for resident and inflammatory cells. This factor is present on the inflammation initial phases and for this reason it was expected the peak of TNF- $\alpha$ expression to occur in all groups on the sixth day, due to the extraction stimulus. Similarly to the inflammatory infiltrate, group II presented higher expression of TNF- $\alpha$, for all the periods, while the least expression was for group I (Figure 4E). For the control group, the inflammatory stimulus was less intense when compared to the infected groups, hence the results are coherent. Besides that, there was a continuous decrease of its expression, corresponding to what was microscopically evidenced by the reduction of the number of inflammatory cells. Consequently, there was a positive correlation between the variables analyzed, indicating that the quantification of TNF- $\alpha$ constitute a reliable parameter to analyze the inflammation present in dry socket. Group II presented almost the double of TNF- $\alpha$ expression, when compared to other groups and the inflammatory infiltrate was also very expressive (Figure 4E). With the infection and higher production of TNF- $\alpha$, there was greater stimulus for inflammatory cells migration to the site and consequently higher inflammatory infiltrate density, as observed previously. In fact, microbial products activate resident and inflammatory cells, leading to the production of inflammatory mediators, among them TNF- $\alpha^{14,15}$. Groups III and IV presented a decrease of the variables along the period and did not present significant differences (Figure 4E). The explanation for the reduction of the inflammatory response for groups III and IV is probably due to the treatments employed. The expression of TNF- $\alpha$ was reduced after the treatment, decreasing the stimulus for cells migration and consequently causing a reduction of the inflammatory infiltrate. Group IV presented less inflammatory infiltrate that group III and this coincides to higher bone neoformation (Figure 5G). Concerning to bone neoformation density, it was observed a negative correlation. In fact, the inflammatory site, characterized by high levels of TNF- $\alpha$, does not favor osteoblastic differentiation and activity, which probably contributes directly for lower bone neoformation, observed in group II and in lower intensity for groups III and IV. The expression of TNF- $\alpha$, was considered an applicable parameter for the analysis of induced dry socket when correlated to bone neoformation and inflammatory infiltrate. Besides that, the correlation between clot density and TNF- $\alpha$ was significant (Figure 5F). This fact is probably due to higher expression of TNF- $\alpha$ in the groups in which there was a repair delay, because of the contamination and higher clot presence, due to the delay in tissue substitution.

VEGF expression was correlated to the presence of blood vessels (Figure 5I). VEGF may be produced by macrophages, 
lymphocytes or even by resident cells of the conjunctive tissue and its production may be increased in hypoxia conditions, in wound healing and during the repair process. VEGF is present when there is vascular proliferation and on the initial stages of the inflammation it is present in higher quantity. VEGF expression did not present significant differences between the groups and its correlation to the blood vessels density in each group it was not very different. This fact shows that the quantification of the VEGF expression is not applicable to evaluate blood vessels density.

\section{Conclusion}

We can conclude that no significant difference was found among the treatments. Only the RUNX2, OCN and TNF- $\alpha$ markers can be used as indicators to evaluate the dry socket bone neoformation and inflammatory infiltrate (quantitatively) in rats. Although the preference of researchers for microscopic analysis, we believe this is the beginning of a new methodology for analysis of bone repair process, which should be further studied.

\section{References}

1. Blum IR. Contemporary views on dry socket (alveolar osteitis): a clinical appraisal of standardization, aetiopathogenesis and management: a critical review. Int J Oral Maxillofac Surg. 2002;31:309-17.

2. Colby RC. The general practitioner's perspective of the etiology, prevention, and treatment of dry socket. Gen Dent. 1997;45:461-7.

3. Noroozi AR, Philbert RF. Modern concepts in understanding and management of the "dry socket" syndrome: comprehensive review of the literature. Oral Surg Oral Med Oral Pathol Oral Radiol Endod. 2009;107:30-5.

4. Cardoso CL, Rodrigues MT, Júnior OF, Garlet GP, Carvalho PSP. Clinical concepts of dry socket. J Oral Maxillofac Surg. 2010;68:1922-32.

5. Crawford JY: Dry sockets after extraction. Dental Cosmos. 1896;38:929-31.

6. Carvalho PSP, Okamoto T, Carvalho ACP. The influence of intraalveolar curettage on wound healing after tooth extraction. A histological study in rats. J Nihon Univ Sch Dent. 1982;24:28-34.

7. Carvalho PSP, Mariano RC, Okamoto T. The treatment of fibrinolytic alveolitis with rifamycin b diethylamide associated with gelfoam: a histological study. Braz Dent J. 1997;8:3-8.

8. Rodrigues MTV, Cardoso CL, Carvalho PSP, Cestari TM, Feres M, Garlet GP, Ferreira-Júnior O. Experimental alveolitis in rats: microbiological, acute phase response and histometric characterization of delayed alveolar healing. J Appl Oral Sci. 2011;19:260-8.

9. Socransky SS, Smith C, Martin L, Paster BJ, Dewhirst FE, Levin AE. "Checkerboard" DNA-DNA hybridization. Biotechniques. 1994; 17:788-92.

10. Garlet GP, Cardoso CR, Campanelli AP, Garlet TP, Avila-Campus MJ, Cunha FQ, Silva JS. The essential role of IFN-gamma in the control of lethal Aggregatibacter actinomycetemcomitans infection in mice. Microbes Infect. 2008;10:489-96.

11. Silva LJ, Poi WR, Panzarini SR, Rodrigues TS, Simonato LE.
Clinical evaluation of an ointment with $10 \%$ metronidazole and $2 \%$ lidocaine in the treatment of alveolitis. Minerva Stomatol. 2006;55:431-6.

12. Poi WR, Carvalho PSP, Okamoto T. Efeito da pasta à base de metronidazol, lidocaína e ascorbosilone $\mathrm{C}$ sobre o processo de reparo de alvéolos dentais infectados de ratos. Rev Bras Cir Impl. 2000; 7:22-80.

13. Poi WR, Carvalho PSP, Okamoto T. Influência da pasta à base de metronidazol a 10 por cento e lidocaína a 2 por cento sobre o processo de reparo em alvéolo dental infectado. Análise histológica e histométrica em ratos. Rev Odontol UNESP. 1998;27:53-72.

14. Mukai T, Otsuka F, Otani H, Yamashita, Takasugi K, Inagaki K, Yamamura M, Marino H. TNF-alpha inhibits BMP-induced osteoblast differentiation through activating SAPK/JNK signaling. Biochem Biophys Res Commun. 2007;356:1004-10.

15. Yamshita M, Otsuka F, Mukai T, Otani H, Inagaki K, Miyoshi T, Goto J, Yamamura M, Makino H. Simvastatin antagonizes tumor necrosis factor-alpha inhibition of bone mosphogenetic proteins2-induced osteoblast differentiation by Smad signaling and Ras/ Rho-mitogen-activated protein kinase pathway. J Endocrinol. 2008;196:601-13.

\section{Correspondence:}

Camila Lopes Cardoso

Depto de Cirurgia/Faculdade de

Odontologia de Bauru/USP

Al. Octávio Pinheiro Brisolla, 9-75

17012-901 Bauru-SP Brasil

cardoso_lopes@yahoo.com.br

Received: January 13, 2011

Review: March 17, 2011

Accepted: April 18, 2011

Conflict of interest: none

Financial source: FAPESP and CAPES 